\title{
Matilda and the Mythologisation of Miss Honey and Miss Trunchbull
}

\author{
Branwen Bingle \\ 0000-0002-2685-2610 University of Greenwich, United Kingdom \\ b.m.bingle@greenwich.ac.uk
}

\begin{abstract}
The power of children's literature is such that a significant number of teachers in the UK take the texts they read as children into the classroom to share with future generations. One of the most popular authors is Roald Dahl; and his most popular title among practitioners is Matilda. As a result, the characters of Miss Honey and Miss Trunchbull have become highly influential in the cultural construction of the literary primary teacher, and even influenced real teachers' decision to train as educators. In light of the potential interplay between imagined teachers and the identity construction of teachers in training it is important to analyse what constructs the teacher are being offered in this most significant of works. In this article I investigate the way that teaching and teachers are presented by Dahl in order to examine the sociocultural constructs he offers children regarding the role and the people who choose to undertake it.
\end{abstract}

Keywords: Roald Dahl; Matilda; teachers; sociocultural constructs; identity; children's literature

\section{Introduction}

One of the most well-known titles in UK children's fiction is Roald Dahl's Matilda. Written in 1988 and with original illustrations by Quentin Blake, it is a popular choice for teachers when choosing texts to share with primary aged pupils. The findings of the Teachers as Readers (TARs) interim report (Cremin et al. 2007, 4) found that, in terms of teachers' own favourite childhood reading, "Blyton and Dahl were by far the most mentioned authors". But it was Dahl alone who received more than double the number of mentions over any other author in response 
to the request to name "good children's writers" (Cremin et al. 2007, 5): of the 1200 primary teachers surveyed by the project, 744 identified him and his work in the fiction and poetry sections. In addition, recent doctoral research which explored the interplay between representations of teachers in children's literature and learners' notions of teaching (Bingle 2017) found that one respondent made an explicit link to memories of having Matilda (Dahl $1988 / 2016^{1}$ ) read to her as a child, citing the narrative as pivotal in her early ambition to teach. The participant was inspired by the impact she deemed Miss Honey had on Matilda's life, as well as the fictional teacher's popularity. Interestingly, she called this response a cliché, indicating she assumed others were inspired the same way by this text in particular. However, another participant mentioned during the data collection process that she had always rather disliked Miss Honey for being a poor example of a teacher. Although expressing opposing views, both responses, along with the frequency of the text's citation in response to the question regarding books with teachers as characters, indicate that Dahl's (1988/2016) omnipresent tale has an impact on constructions of the role.

This influence comes despite an apparent academic distrust of Dahl's popularity with child readers. Culley $(1991,59)$ details some of the concerns over Dahl's "vulgarity, fascism, violence, sexism, racism, occult overtones, promotion of criminal behavior [sic], and literary technique". Thus Dahl's body of work was dismissed by critics, during his lifetime and beyond, for being questionable in some of the implicit messages in his plots and/or characterisations (Butler 2012), and even as a result of the "prejudice" against commercially popular texts that have appeal for children (Campbell 1981; Rudd 2013). However, it would certainly appear that those same children have grown up into teachers who remember the enjoyment of his stories from their childhood perspective rather than allowing adult sensibilities to affect their views.

The endorsement by the educational establishment creates quite a paradox, as Dahl revelled in being subversive and viewed himself as "the voice of youth" in a world where adults were "the enemy" to children (Sturrock 2010,547). Dahl was unashamedly on the side of the young reader in his approach; unlike C. S. Lewis (1966/1982) he saw no need to appeal to the reader beyond childhood. This ironic contradiction has left many commentators baffled by the continual presence of Dahl's stories in the classroom, particularly given his seeming ambivalence towards authority in general and teachers in particular (Maynard and McKnight

1 Henceforth, I shall refer to the primary text with page numbers only. 
2002; Pinsent 2012); indeed, it is even more peculiar that teachers in primary settings appear to have developed an “"over dependence' on Dahl” (Cremin et al 2007, 8). However, others have recognised elements of a long "progressive, liberal tradition dating back to Aesop" (Grenby 2014, 24) in his writing, which might, when coupled with his reputed ability to engage even those considered reluctant readers, explain his popularity with educators.

Matilda is typical of Dahl's anarchic style of writing for children: as Butler $(2012,1)$ remarks, "he was (and remains) controversial", even in British children's literature circles where black humour is more prevalent than in other cultures (O'Sullivan 2005, 29). It is interesting to note that Matilda was published in the same year as Dahl was invited to join, and swiftly resigned from, the government working party headed by Professor Brian Cox and commissioned to review the teaching of English in UK schools, leading to the publication of the Cox Report (DES 1989). A single meeting of the committee had been enough to frustrate him about the lengthy, convoluted process involved. Perhaps it was for the best, for although Dahl appears as one of the recommended authors in the interim report (DES 1988), according to one of his more well-known biographers "he wasn't unequivocally on the same side as the Conservative powers-that-were" and "Matilda [...] is among other things an onslaught on Gradgrindian teaching methods" (Treglown 1994, 268). That said, the first drafts of the tale presented very different representations of the teachers we now recognise (Sturrock 2010; Treglown 1994), though their fundamental disagreement over the best method to educate children was always an integral part of the tale: Miss Hayes the inveterate gambler and Miss Trunchbull, still very much a bully but less pivotal to the story, would not necessarily have had the cultural impact of the famous (and infamous) characters which eventually emerged. Miss Hayes in particular would not have been revered in the same way as her successor in the story.

However, it is not actually the well-known fictional teacher-characters of Matilda that we meet first of all. Within the opening pages of the story, Dahl interjects a brief interlude of literary realism, addressing the reader directly in an immediate aside from which we can derive much about his views on the nature of teaching. The first teachers we are introduced to, on page 2, are what Dahl presents as authentic teachers in the real world: 
School teachers suffer a good deal from having to listen to this sort of twaddle from proud parents, but they usually get their own back when the time comes to write the end-of-term reports.

There are several interesting constructs presented, even in this simple statement. The first is the suggestion that teachers "suffer a good deal", which is in reference to listening to overlyand inappropriately-proud parents express delusions about their children's genius. The implication is that the teachers are powerless to correct the parents in conversation, and are unable to prevent or curtail the interaction, in other words:

$\begin{array}{ll}\begin{array}{l}\text { Teachers have to put up } \\ \text { with a good deal from }\end{array} & \begin{array}{l}\text { Teachers are able to control the } \\ \text { situations they get into with } \\ \text { parents }\end{array} \\ \begin{array}{l}\text { parents; they do not have to } \\ \text { tolerate them }\end{array} \\ \begin{array}{l}\text { Teachers have to listen to } \\ \text { parents and accept what }\end{array} \\ \begin{array}{l}\text { Teachers can disagree with } \\ \text { they are told about their } \\ \text { children }\end{array}\end{array}$

This is followed by another implicit assumption that not only is report-writing one of the only ways teachers can have a "voice", but that this is seen as an opportunity for revenge ("get their own back") and some form of restorative justice:

\begin{tabular}{|c|c|c|}
\hline $\begin{array}{l}\text { Teachers usually use the } \\
\text { formal report process to } \\
\text { get their own back }\end{array}$ & as opposed to & $\begin{array}{l}\text { Talking honestly to parents } \\
\text { throughout the year }\end{array}$ \\
\hline $\begin{array}{l}\text { Teachers know the truth } \\
\text { about the children they }\end{array}$ & as opposed to & $\begin{array}{l}\text { Parents are blinded to the faults } \\
\text { of their children }\end{array}$ \\
\hline
\end{tabular}

Present right from the beginning, then, is the idea that teachers are ineffective due to their defencelessness in the face of parents' expectations on a day-to-day basis, but that in the finality of the end-of-term report, where they are allowed to put into writing their personal and 
professional judgment, they can be honest about pupils' capabilities to the point of rudeness with no fear of reprisal. Dahl enters a brief fantasy scenario in which he describes the sorts of reports he would write if he were a teacher; they are written in increasingly humorous and derogatory ways about hapless imaginary children he deems "stinkers" in his invented class, although it is questionable as to whether the stinkers he describes are individuals or the entire cohort. The comments are completely in keeping with his style, revelling in his own cleverness, so we are left in no doubt these are the reports Dahl would write, questioning the employability of one child before casting aspersions about the hearing capabilities of another. A third child's performance is likened to that of an insect's larvae while a fourth is not only deemed shallow, but is blamed for goading Teacher-Dahl into his response (3)

A particularly poisonous little girl might sting me into saying, 'Fiona has the same glacial beauty as an iceberg, but unlike the iceberg she has absolutely nothing below the surface.'

What is interesting here is that Dahl is suggesting that the report itself has no relevance for the child; the insults are not meant to wound the pupils they refer to, they are aimed as salvos at the parents. This indicates the assumption that, certainly in the case of the pampered and overprivileged child, teachers and parents are in conflict, benign as it may be during the year, when the constructs proposed above suggest parents seem to have the upper hand.

There is an underlying scholarly tone to the bullying use of language, with frequent scientific references designed to prove the writer's (both actual Dahl and Teacher-Dahl) cleverness in the face of clearly (in his view) stupid parents. Thus the taunting and tormenting Dahl undertakes in the comments is not intended to suggest that teachers dislike the children in their care, or that if they did they would make this dislike clear to the pupil involved; however, what it does indicate is that dialogue and communication between home and school happens which excludes the child, and that you (the pupil) may not know, unless your parents tell you, what your teacher really thinks of you.

There is also an inverted example of double address (Nikolajeva 2005): rather than the adult being addressed over the head of the child, Dahl is addressing children over the heads of their parents and their teachers. For all the scientific terminology, Teacher-Dahl is writing the reports 
the way he expects children getting their own back would, with clever insults and childish taunting. Dahl brings this brief but loaded aside to an end with an abrupt "But enough of that. We have to get on" (3) but there is a sense he could think of many more ways to plague parents if he were a teacher, and would take great delight in doing so.

While school is briefly mentioned on page 6 - "Her brother (five years older than her) went to school" - it is not until page 60, over a quarter of the way through the book, that we are introduced to the setting and the teachers synonymous with the story. Dahl describes the village school as "a bleak brick building called Crunchem Hall Primary School" (3) and provides us with the detail that the school "had about two hundred and fifty pupils aged from five to just under twelve years old" (3).

This description offers two noteworthy details regarding teaching staff at the school. One is the play on words suggested by the name of the school, which begs the question who is it will crunch 'em? And indeed, who is being crunched? The connotation is that something menacing resides at the school ready to chew up the children and spit them out, to quote a common idiom. The second is the specificity of the number of children that attend Crunchem Hall. The size of school described by Dahl, even in the 1980s when the book was written and class sizes for children aged seven and under were not capped at 30 pupils as they are in contemporary UK classrooms, would have necessitated at least seven classes (a reception class, two year groups in the infants, two in the lower juniors and two in the upper juniors). Neither Dahl nor his children ever attended a government maintained day school, and so much of his description of Matilda's school is charmingly archaic or distorted, including the idea that Matilda, who is supposedly starting school late, would have been put in what Dahl calls "the bottom class" (60) at all with children younger than her if she should have been in the next year group. He later seems to suggest that all the children in the class are five, the same age as Matilda, and that this is their first day too. This is where Dahl's lack of knowledge of state schooling is demonstrated, as he is very clear that "six years" (63) will be spent at Crunchem Hall, so seemingly Matilda has ended up in the first year infants' class she should have been in at exactly the right age and on the same day as all of the eighteen other new pupils. Herein lies the biggest mystery: if there are only 18 children in Matilda's class it stands to reason there would be a parallel group of children the same age, suggesting the school is two-form entry (i.e. two classes per year group), so who and where are the other 11 classroom teachers? They are certainly not part of the 
mythology of Matilda; few people can name the only other teachers given a separate identity in the text (Miss Plimsoll and Mr Trilby), and it is only at the end of the penultimate chapter that we meet five anonymous staff members who come more to gloat at the head teachers demise than to do anything meaningful. This suggests another construct present in Dahl's text, particularly in light of the descriptions soon about to follow of the two well-known members of staff:

Forgettable and As opposed to Memorable and/or infamous unimportant

Our first glimpse of Miss Honey presents her as young, beautiful and nurturing; we are immediately expected to relate to her almost angelic extraordinariness (60):

Their teacher was called Miss Honey, and she could not have been more than twentythree or twenty-four. She had a lovely pale oval madonna face with blue eyes and her hair was light-brown. Her body was so slim and fragile one got the feeling that if she fell over she would smash into a thousand pieces, like a porcelain figure.

Although Dahl makes it quite clear that very few people can ever hope to attain the kind of empathy or understanding Miss Honey is capable of, she is presented as a literal icon, a Motherof-God figurine to be revered and worshipped. She is incognisant of her own divinity; indeed, at no point in the narrative does anybody but Matilda appear to venerate her to the extent suggested here, and even at the end of the book her colleagues seem unaware (or unimpressed) by her natural gifts as a teacher. When Miss Trunchbull is finally vanquished, the nameless staff member who delights in her downfall suggests Miss Honey has finally gained the courage they all lack and turned to violence - "By golly, somebody's floored her at last!" cried one of the men, grinning. "Congratulations, Miss Honey!" (220) - although this could also be read as his teasing of the meek and mild young staff member; and Matilda's new teacher, Miss Plimsoll, "quickly discovered that this amazing child was every bit as bright as Miss Honey had said" (223) rather than taking Miss Honey's word for it. Neither interaction suggests Miss Honey is held in particularly high esteem by her colleagues, but neither do they suggest she is unpopular. When Matilda and Miss Honey arrive at the Wormwood family home to ask if Matilda can stay with her teacher rather than flee the country with her parents, the 
response she receives from Mr Wormwood suggests a far-from-memorable presence: "The father turned and looked at Miss Honey. "You're that teacher woman who once came here to see me, aren't you?" he said. Then he went back to stowing the suitcases into the car" (231-2). The popular view of Miss Honey as universally loved, then, is challenged within the very narrative.

While Miss Honey is presented as a rarity because of her kind and empathetic nature, Miss Trunchbull provides the dualism necessary to fully understand her goodness; as Egan (1997) points out "Forming binary oppositions is a necessary consequence of using language; it is one of our sense-making tools" (37), although he does also note that this can also be used to create damaging stereotypes, particularly with regard to gender and women in particular. In Dahl's case, the binary begins with angel and demon: unlike Miss Honey, Miss Trunchbull is "a gigantic holy terror, a fierce tyrannical monster who frightened the life out of the pupils and teachers alike" (61).

Although Dahl initially presents Miss Trunchbull as atypical a character as Miss Honey, he damages the notion somewhat by stating we will all meet someone like her in our lives, and it would be fair to assume he means while we are at school. This suggests that the sociocultural construction of real teachers offered here positions them as rather mediocre, bland and ordinary, and not possessing any of Miss Honey's rare qualities; but that every educational institution will have a demonic and terrifying staff member à la Trunchbull that is to be avoided whenever possible.

Dahl gives us another insight into his views on real teachers in his description of Miss Trunchbull's leadership qualities (76):

Now most head teachers are chosen because they possess a number of fine qualities. They understand children and they have the children's best interests at heart. They are sympathetic. They are fair and they are deeply interested in education. Miss Trunchbull possessed none of these qualities and how she ever got her present job was a mystery. 
Thus, while Miss Trunchbull is the example of a school leader Dahl has provided us with in Matilda's school, he makes it clear she is not what he expects from real head teachers, who he feels are generally far more deserving of the post because of their child-centredness.

Another interesting facet of the character to consider, and one that underlines Dahl's caricatured version of the novel's antagonist, is Miss Trunchbull's possible status as transgender, or to use an outdated term from the 20th century, transvestite. As Butler $(2012,5)$ points out "[Dahl] was well aware of the power of double entendre in names", and the combination of Trunch, meaning a small wooden post, with Bull as a symbol of extreme masculinity, aggressive and muscular, seems a curious choice. It does offer an extreme contrast to Miss Honey's sweet, nurturing femininity; but when coupled with frequent references to Miss Trunchbull as male ("Nasty dirty things, little girls are. Glad I never was one." (80); "the Trunchbull is the Prince of Darkness, the Foul Serpent, the Fiery Dragon with all the weapons at her command" (103); “'Well thrown, sir!' someone shouted from across the playground") it becomes even more incongruous. In addition, an older pupil regales Matilda and her fellow classmate Lavender with stories of Miss Trunchbull's previous career as an athlete: "You've got to remember that the Trunchbull once threw the hammer for Britain in the Olympics so she's very proud of her right arm" (104). This is not problematic until the reader realises that Miss Trunchbull could only have competed in this sport at this level if she was a man, as women have only been able to compete at hammer-throwing in the Olympics since 2000 (IAAF n.d.); Dahl may have been unaware of this fact, or simply ignored it for the sake of the narrative. However, the older pupil, Hortensia, had previously referred to a practical joke she had played on Miss Trunchbull, putting itching powder in the head teacher's gym knickers after sneaking into her room at school (101-2).

"Well," Hortensia said, "a few days later, during prayers, the Trunchbull suddenly started scratching herself like mad down below. A-ha, I said to myself. Here we go. She's changed for gym already. It was pretty wonderful to be sitting there watching it all and knowing that I was the only person in the whole school who realised exactly what was going on inside the Trunchbull's pants. And I felt safe, too. I knew I couldn't be caught $[\ldots]$ " 
While I have no doubt many other readers have put these clues to Miss Trunchbull's character together to form entirely different constructs, I cannot help wondering if Dahl was not deliberately presenting a final binary: Miss Honey is not only the archetypal teacher versus the non-teacher that is Miss Trunchbull; she is the real feminine article to Miss Trunchbull's pseudo-womanhood. Times have changed since Dahl wrote Matilda, and transgender rights are now enshrined in equalities law alongside other protected characteristics; but at the time of writing in 1988 the world was not so enlightened. Miss Trunchbull could and has been read as a sort of pantomime dame, a female role played by a man for comic effect, and indeed this interpretation has informed a recent musical stage play based on the narrative written by Dennis Kelly and Tim Minchin (Cohen 2013). The film draws on a tradition of transvestism peculiar to the UK in a way the 1996 film directed by Danny DeVito did not in its casting of a woman in the role (Masters 2011). However, within the original text Miss Trunchbull had lived as a woman for the whole of Miss Honey's life (she is, in fact, Miss Honey's aunt) and is to all intents and purposes a female character. Whatever the truth of the matter, Miss Trunchbull is not what she seems, and her status as Miss Honey's aunt is not the only secret hinted at throughout the narrative as one she wants to hide.

Both of the main teacher characters are described in extensive detail, both in terms of physical attributes and disposition, but they are also both presented visually at different points in the book. Matilda was one of the few stories by Dahl that was originally illustrated by Quentin Blake, although the author and illustrator have become linked to such an extent that Blake's illustrations are considered definitively Dahl. In a biographical paragraph at the beginning of the edition of Matilda studied here it is stated that Blake was "Roald Dahl's favourite illustrator", and thus it is fair to assume that the illustrations represent the characters precisely as Dahl intended. Blake's first illustration of Miss Honey shows her surrounded by smiling children, and he effectively conveys in this still image how she is able to give her attention to many members of her class at any one time. Miss Honey is presented as a dynamic presence in the classroom, and the pupils are comfortable in her company. She is interacting with the pupils, and taking part in recognisable classroom activity by handing out the books: she is part of the accepted teaching community of practice.

Our first view of Miss Trunchbull indicates her more solitary, isolated position: she is alone in her room, surrounded by vicious-looking implements and she stares aggressively at the reader, 
challenging them to disobey. The picture on the wall is a mirror image of her stance and does appear to show a much younger, and certainly fitter, hammer-throwing Miss Trunchbull, which highlights the idea that she is a woman with a past, someone who had a previous, non-teaching existence; this is in direct contrast to Miss Honey, who fought to become a teacher directly after finishing school.

That is not to suggest that Dahl has not allowed Miss Honey her own life outside of school: he goes to great lengths to encourage the reader to see her as a person in her own right. When Matilda first visits Miss Honey’s home she is struck by the notion that it had never occurred to her that teachers need somewhere to live (177):

She had always regarded her purely as a teacher, a person who turned up out of nowhere and taught at school and then went away again. Do any of us children, she wondered, ever stop to ask ourselves where our teachers go when school is over for the day? Do we wonder if they live alone, or if there is a mother at home or a sister or a husband?

However, as Miss Honey's tragic tale emerges it becomes apparent that it is only through teaching that Miss Honey has any kind of a life at all.

Dahl goes into great detail in his description of Miss Honey's teacher training, and this is where the story is at its most real while simultaneously being very mistaken. The teacher training college in Reading she describes to Matilda was a real place. However, Dahl did not seem to know that Reading's teacher training establishment (Bulmershe College, Woodley) had degree awarding powers, so although Miss Honey did not go to a university (Bulmershe did not become part of the University of Reading until the year following Matilda's publication) she would still have had a degree. This is indicated in the earlier conversation between Miss Honey and Mrs Wormwood (93-94):

"Matilda's trouble", she said, trying once again, "is that she is so far ahead of everyone else around her that it might be worth thinking about some extra kind of private tuition. I seriously believe that she could be brought up to university standard in two or three years with the proper coaching." 
"University?" Mr Wormwood shouted, bouncing up in his chair. "Who wants to go to university for heaven's sake! All they learn there is bad habits!"

"That is not true," Miss Honey said. "If you had a heart attack this minute and had to call a doctor, that doctor would be a university graduate. If you got sued for selling someone a rotten second-hand car, you'd have to get a lawyer and he'd be a university graduate, too. Do not despise clever people, Mr Wormwood. But I can see we're not going to agree. I'm sorry I burst in on you like this." Miss Honey rose from her chair and walked out of the room.

Miss Honey's could have cited her own BEd degree, awarded by the Council for National Academic Awards (CNAA) due to her attendance at Bulmershe. Dahl's inexperience with the maintained sector of education may have meant he did not know this, or it could have been snobbery, whereby college degrees were considered beneath a university education. For whatever reason, the narrative suggests that teachers do not have the same academic standing as doctors or lawyers.

The key to Miss Honey's success with her learners then is not presented as due to her intelligence or academic ability, but rather her pedagogic methods. The pupils enthusiastically describe how she uses mnemonics, songs and rhymes to help them learn, approaches that are sneered at by Miss Trunchbull (140-1):

“All right," said Nigel, wobbling crazily on his one leg. "Miss Honey gives us a little song about each word and we all sing it together and we learn to spell it in no time. Would you like to hear the song about 'difficulty'?"

"I should be fascinated," the Trunchbull said in a voice dripping with sarcasm.

"Here it is," Nigel said.

"Mrs D, Mrs I, Mrs FFI

Mrs C, Mrs U, Mrs LTY.

That spells difficulty."

"How perfectly ridiculous!" snorted the Trunchbull. "Why are all these women married? And anyway you're not meant to teach poetry when you're teaching spelling. Cut it out in future, Miss Honey." 
Thus Miss Trunchbull, who has no discernible teaching qualification despite attaining the position of head teacher, dictates a particular kind of curriculum delivery based on rote learning, while Miss Honey demonstrates the power of multisensory strategies and approaches that enthuse learners.

Miss Honey is not universally effective, however. In her first appearance, as she tries to grapple with Matilda's genius, she leaves the rest of the class sitting at their desks watching her question the solitary child prodigy; she is forced to work out using pencil and paper a sum Matilda worked out mentally with ease; and she is not above lying to her pupils in order to avoid answering difficult questions.

In addition, she is ultimately unable to solve her own problems; it takes a five-year-old girl with special powers to address the injustices in Miss Honey's life. Nevertheless, throughout the book, illustrations of Miss Honey demonstrate her natural ability in the classroom: they show her interacting with pupils in a relaxed manner and whenever she is pictured looking at pupils in the classroom she is drawn smiling. Miss Trunchbull, on the other hand, is depicted as intimidating and fierce with the pupils in the school, towering over or pointing threateningly at children, and in several instances, both in illustration and text, she is physically abusive. And yet there is never a suggestion that the Trunchbull's authority will be curtailed or her reign of terror ended by any other adult with a duty of care to the pupils (110):

"She's mad," Hortensia said.

“But don't the parents complain?” Matilda asked.

"Would yours?" Hortensia asked. "I know mine wouldn't. She treats the mothers and fathers just the same as the children and they're all scared to death of her. I'll be seeing you some time, you two." And with that she sauntered away.

Matilda subsequently identifies a second source to Miss Trunchbull's power when Lavender questions why children do not complain to their parents, although it seems contrary to that indicated above (111):

Matilda said, "Never do anything by halves if you want to get away with it. Be outrageous. Go the whole hog. Make sure everything you do is so completely crazy it's 
unbelievable. No parent is going to believe this pigtail story, not in a million years. Mine wouldn't. They'd call me a liar."

"In that case", Lavender said, “Amanda's mother isn't going to cut her pigtails off." "No, she isn't," Matilda said. "Amanda will do it herself. You see if she doesn't."

Because pupils, and one must assume staff, know she will act upon any threat she makes, they self-regulate to avoid her wrath, and when they do not the consequences are comically terrifying. Miss Trunchbull uses unfortunate children to practice her hammer-throwing, she picks up another by the ears, stretching them in such a way as it is noticeable to his parents, and a third is pulled out of his chair by his hair and held up, legs waving, until he recites his times tables to her satisfaction. Miss Trunchbull is thus more than the ultimate authority in the school; she is a tyrannical despot and all are powerless against her.

And yet regularly throughout the book this is shown as not the case at all. When Miss Trunchbull tries to humiliate Bruce Bogtrotter her plan goes awry: Bruce was not only brave (or foolish) enough to steal the cake in the first place, he spectacularly circumnavigates her plan to make him gorge himself until he throws up in front of the whole school. Bruce triumphs by eating the whole cake Miss Trunchbull has forced on him, and while the entire school cheers, Miss Trunchbull looks on, defeated. Clearly there are some lengths even she will not go, and as Bruce has passed her version of trial by fire she must accept he has earned the right to avoid further punishment.

But Bruce is not the only pupil willing to risk her ire. Hortensia's stories include more than one practical joke she has played on the head teacher, and her disdain is clear right from her first meeting with Matilda: "Have you met the Trunchbull yet?" (96) she asks the younger pupil, discarding her title as a first step in indicating her lack of respect for this particular teacher. Even Matilda's classmate Lavender is willing to challenge Miss Trunchbull's authority, albeit not overtly, by placing a newt in her water jug before she teaches them.

Although Matilda gets blamed for the incident and Lavender is too frightened to own up to the prank, these small acts of rebellion seem to be more than the teaching staff are doing to shake Miss Trunchbull out of her position of authority. In all of her dealings with Miss Honey she emerges triumphant, although this becomes more understandable after we learn the truth about 
their relationship. In their first interaction in the text, Miss Honey's attempts to persuade Miss Trunchbull of Matilda's genius are dismissed (83):

Miss Honey stood there helpless before this great red-necked giant. There was a lot more she would like to have said, but she knew it was useless. She said softly, "Very well, then. It's up to you, Headmistress."

In the same conversation, Miss Trunchbull shows herself to be a poor judge of character when she extolls the virtues of Matilda's father, a man already introduced to the reader as underhand and dishonest. Miss Honey, on the other hand, is perceptive and astute, having identified Matilda's talents within the first lesson they share. She attempts to engage Matilda's parents in order to help her get the educational support she deserves, but here Dahl's earlier disdain for parents surfaces again: they are not as intelligent or as nurturing as their daughter's teacher, and thus unable to see why they should care about her education.

At this point Mrs Wormwood also makes clear her contempt for the spinster-teacher she sees before her, highlighting Miss Honey's vocation and her lack of a husband as indicators she has failed in life (92):

Miss Honey looked at the plain plump person with the smug suet-pudding face who was sitting across the room. "What did you say?" she asked.

"I said you chose books and I chose looks," Mrs Wormwood said. “And who's finished up the better off? Me, of course. I'm sitting pretty in a nice house with a successful businessman and you're left slaving away teaching a lot of nasty little children the ABC."

While Dahl certainly does not paint the Wormwoods as characters he expects the reader to empathise with, it is interesting to note that all three named female teachers are referred to as Miss. Miss Trunchbull does not appear interested in family, and Miss Plimsoll has no other identifiable attributes that would allow us to draw conclusions about her life, but they are both resolutely presented as unmarried. Miss Honey is presented as dedicated to her role as a teacher; she is also identified as 23 or 24 years in age and thus young enough not to have considered marriage or starting a family. But the fact that no healthy familial relationships are 
portrayed until Miss Honey becomes Matilda's guardian adds credence to the myth that teachers have no life outside of the classroom environment.

As indicated previously, the relationship between Miss Honey and Miss Trunchbull is not actually that of head teacher and staff member: Miss Trunchbull is Miss Honey's maternal aunt and her legal guardian since the untimely death of her father when she was five years of age. The chapter entitled "Miss Honey's Story" details how Miss Honey has suffered years of physical and mental abuse at the hands of Miss Trunchbull, which suddenly makes her inability to stop her aunt's mistreatment of her pupils understandable: she was unable to protect herself, and thus, while she does what she can for her pupils, she is powerless to break the cycle of abuse on her own. Miss Honey feels unable to prevent the abuse of her pupils, and the advice she gives them in dealing with her or not provoking her comes from her own experience (128).

\footnotetext{
"A word of warning to you all," Miss Honey said. "The Headmistress is very strict about everything. Make sure your clothes are clean, your faces are clean and your hands are clean. Speak only when spoken to. When she asks you a question, stand up at once before you answer it. Never argue with her. Never answer back. Never try to be funny. If you do, you will make her angry, and when the Headmistress gets angry you had better watch out."
}

While this makes Miss Honey once again a character of flesh and blood as opposed to bland and flat as so many teachers in literature are, it does not excuse the lack of action or even presence of the other teachers in the school. Miss Honey has a life outside school that none of her pupils could possibly guess; and it is upon discovering the lengths Miss Honey has had to go to take any sort of ownership of this life that she becomes a hero to Matilda (197):

Matilda stared at her. What a marvellously brave thing Miss Honey had done. Suddenly she was a heroine in Matilda's eyes.

It is not Miss Honey the teacher but Miss Honey the survivor that Dahl is celebrating; and he rewards her with a ready-made family rather than a promotion once Miss Trunchbull is finally vanquished. Instead it is the "Excellent Mr Trilby" (222), a deputy head we do not meet until the final chapter of the book, and who was not excellent enough to prevent Miss Trunchbull's 
reign of terror, who is promoted to head at the instigation of the equally culpable governing body. Maybe Mrs Wormwood's barb about successful women and their place in the home was closer to Dahl's construct of what ought to be than the embodiment of the exceptional teacher that has entered the sociocultural consciousness.

Miss Honey and Miss Trunchbull are characters that have become very much part of what Weber and Mitchell (1995/2003) referred to as the sedimentary basis for understanding the role of the teacher within the UK, and perhaps, because of the number of translations and copies sold, globally. But as Egan (1997) warned, the sort of binary opposition offered here presents extremes that are unobtainable by ordinary beings: Miss Trunchbull is too awful to act as a cautionary tale for those who do not treat the profession with respect by taking their responsibilities to learners seriously; and Miss Honey is too good, too altruistic, too beloved to ever be an effective role model. Dahl has given the teaching profession a terrible cross to bear, for how can we ever be that wonderful?

Such characters encourage unrealistic expectations of the teacher-pupil relationship if nothing else, but perhaps, for Dahl, that is the point. It was not unusual for Dahl to focus on the power of the individual to succeed despite, rather than because, of their education; in his memoir, Boy (Dahl 1984/2016), he recalls school as simultaneously a place of violence and excitement, with a small number of teachers who inspired and many more who lacked any appreciation of his abilities. The head teachers in his life, such as Mr Coombes and the clergyman at Repton who later became Archbishop, were, in Dahl's view, questionable owing to their willingness to use corporal punishment against children. This real-life (if embellished) view, in which real people behaved as monstrously as fictional ones, underpins Matilda: as Pinsent (2012,70) points out, “The contrast in Matilda (1988) between the angelic Miss Honey, who recognises her pupil's potential, and the brutal Miss Trunchbull, who is adamant about the limitations of young children, is consistent with Dahl's views about the weaknesses of the educational system." Thus, one of the most iconic teacher narratives is not actually about the power of good teachers to inspire, it is about the flawed inconsistency of the teachers in our schools and pupils' ability to rise above them. 


\section{References}

Bingle, Branwen M. 2017. “Those Who Can, Teach: The Formative Influence of Socio-Cultural Constructions of Teachers in Children's Literature and Learners' Notions of Teaching." $\mathrm{PhD}$ dissertation, University of Worcester.

Butler, Catherine. 2012. "Introduction". In Roald Dahl, edited by Ann Alston, and Catherine Butler, 1-13. London: Palgrave Macmillan. https://doi.org/10.1007/978-1-137-28504-1_1.

Campbell, Alisdair. 1981 “Children's Writers: 6 Roald Dahl.” The School Librarian 29 (2): 108-114.

Cohen, Patricia. 2013. "He Made Her Who She Is." New York Times, 8 May. Accessed 1 October 2017. http://www.nytimes.com/2013/05/12/theater/theaterspecial/bertie-carvel-asagatha-trunchbull-in-matilda.html.

Cremin, Teresa, Eve Bearne, Marilyn Mottram, and Prue Goodwin. 2007. "Teachers as Readers: Phase 1 (2006-7) Research Report.” Accessed 31 January 2017. https://ukla.org/downloads/TARwebreport.doc.

Culley, Jonathon. 1991. 'Roald Dahl - 'It's about Children and It's for Children' - But is it Suitable?" Children's Literature in Education 22 (1): 59-73. https://doi.org/10.1007/BF01139908.

Dahl, Roald. 1984/2016. Boy. London: Penguin.

Dahl, Roald. 1988/2016. Matilda. London: Puffin.

DES. 1988. English for Ages 5 to 11 (Interim Report). London: HMSO.

DES. 1989. English for Ages 5 to 16 (The Cox Report). London: HMSO.

Egan, Kieran. 1997. The Educated Mind: How Cognitive Tools Shape Our Understanding. Chicago: University of Chicago Press. https://doi.org/10.7208/chicago/9780226190402.001.0001.

Grenby, Matthew, Orville. 2014. Children's Literature. 2nd ed. Edinburgh: Edinburgh University Press. 
IAAF. n.d. "Hammer Throw.” Disciplines. Accessed 31 January 2017. https://www.iaaf.org/disciplines/throws/hammer-throw.

Lewis, Clive, S. 1966/1982. On Stories: And Other Essays on Literature. San Diego: Harvest Books.

Masters, Tim. 2011. "Bertie Carvel plays Miss Trunchbull in Matilda The Musical.” BBC News Entertainment and Arts, 7 December. Accessed 1 October 2017. http://www.bbc.co.uk/news/entertainment-arts-16036102.

Maynard, Sally, and Cliff McKnight. 2002. "Author Popularity: An Exploratory Study Based on Roald Dahl". New Review of Children's Literature and Librarianship 8 (1): 153-175. https://doi.org/10.1080/13614540209510665.

Nikolajeva, Maria. 2005. Aesthetic Approaches to Children's Literature. Lanham: Scarecrow Press.

O’Sullivan, Emer. 2005. Comparative Children's Literature. Abingdon: Routledge.

Pinsent, Pat. 2012. “'The Problem of School': Roald Dahl and Education.” In Roald Dahl, edited by Ann Alston, and Catherine Butler, 70-85. London: Palgrave Macmillan.

Rudd, David. 2013. Reading the Child in Children's Literature: A Heretical Approach. Basingstoke: Palgrave Macmillan. https://doi.org/10.1007/978-1-137-32236-4.

Sturrock, Donald. 2010. Storyteller: The life of Roald Dahl. London: Harper Press.

Treglown, Jeremy. 1994. Roald Dahl: A Biography. London: Faber and Faber.

Weber, Sandra, and Claudia Mitchell. 1995/2003. That's Funny, You Don't Look Like a Teacher! Interrogating Images and Identity in Popular Culture. London: Falmer Press. https://doi.org/10.4324/9780203453568. 